RADOSEAW PAWEE ŻURAWSKI VEL GRAJEWSKI

Instytut Historii Uniwersytetu Łódzkiego

\title{
ROZWAŻANIA O UPADKU I ODRADZANIU SIĘ PAŃSTW (Z OKAZJI SETNEJ ROCZNICY ODZYSKANIA PRZEZ POLSKĘ NIEPODLEGŁOŚCI)
}

Upadek państwa polskiego pod koniec XVIII w., wciąż wówczas jednego $\mathrm{z}$ rozleglejszych terytorialnie $\mathrm{w}$ Europie, o ponad ośmiusetletniej nieprzerwanej tradycji istnienia i funkcjonowania (w tym przez niemal 300 lat jako mocarstwa) na arenie międzynarodowej, jak również jego odrodzenie w 1918 r. nadal - i zapewne jeszcze długo - będą stanowiły wdzięczny przedmiot do rozważań dla historyków i politologów. Pod względem faktograficznym proces ten opisano i przeanalizowano już w tysiącach monografii i artykułów. W niniejszym szkicu na tym polu niczego nowego nie sposób zaprezentować. Jednakże porównanie losów upadku i odbudowy Rzeczypospolitej z okolicznościami, jakie towarzyszyły katastrofom innych podmiotów politycznych oraz udanym próbom ich dźwignięcia z niebytu i powrotu do funkcjonowania na arenie międzynarodowej, może prowadzić do interesujących spostrzeżeń, jak również do uogólniających wniosków wskazujących na istnienie (bądź nie) jakichś generalnych reguł, dających się zaobserwować przy opisywaniu tego rodzaju fenomenów.

Spróbujmy zatem przyjrzeć się kwestii warunków ramowych, które muszą być spełnione w części lub w całości, aby doszło do upadku państwa, wskazać te okoliczności, które sprzyjają zaistnieniu tego typu kryzysu politycznego lub go prowokują, ocenić, czy istnieje jakaś „masa krytyczna" owych okoliczności lub ich hierarchia ważności (tj. czy jedne z nich są niezbędne dla wystąpienia kryzysu i go determinują, a inne są zaledwie prawdopodobne i mogą, ale nie muszą mu towarzyszyć), czy też wystarczy pojawienie się pojedynczej, za to fundamentalnej 
przyczyny, która rozstrzyga o zaistnieniu i przebiegu owego procesu. Podobny zestaw pytań możemy zadać odnośnie do problemu odradzania się państw po okresie ich politycznego niebytu.

Upadek państwa musi mieć źródła w jego słabościach - obiektywnych lub względnych, oczywistych (tj. łatwych do zauważenia i stwierdzenia), ale i ukrytych, podkopujących jego siły w dłuższym okresie. Najczęściej zresztą wiele negatywnych czynników oddziałuje na rozwój kryzysu jednocześnie. Nigdy nie przebiega on jednak jako proces czysto wewnętrzny. Zawsze rozwija się w jakimś otoczeniu międzynarodowym, które nań oddziałuje w zróżnicowany sposób - może starać się go powstrzymać, zainicjować lub przyspieszyć. A zatem owe warunki ramowe tworzy nie tylko kondycja wewnętrzna państwa, ale także działania o zmiennych wektorach (wspierające jego przetrwanie lub przyspieszające upadek) innych podmiotów politycznych.

Historia państwa polskiego dostarcza nam przykładów ilustrujących owe zmienne sytuacje. Kryzys monarchii pierwszych Piastów ${ }^{1}$ pod koniec panowania Mieszka II doprowadził do najazdów na potężną do niedawna Polskę, odziedziczoną po epoce Bolesława Chrobrego, wszystkich jej sąsiadów (Niemców, Rusinów, Czechów), co w efekcie przyniosło utratę części zdobyczy terytorialnych pierwszego króla (Łużyc, Grodów Czerwieńskich, Moraw), chaos w państwie, bunt pogański, czasowe oddzielenie się Mazowsza, zagarnięcie Śląska przez Czechów i upadek autorytetu władzy centralnej. Okazało się, że kryzys ów miał jednak charakter przejściowy i był bardziej reakcją sąsiadów na zbytni wzrost potęgi Polski za czasów Chrobrego niż efektem ich apetytów zaborczych, tudzież rodzimych ruchów odśrodkowych. Kazimierz Odnowiciel (zawdzięczający swój przydomek skutecznej odbudowie państwa, choć w nieco uszczuplonych granicach) mógł bowiem w swych wysiłkach rekonstrukcyjnych liczyć na tych, którzy dopiero co go najeżdżali. Taka zmiana postawy podmiotów zewnętrznych mogła być tylko wynikiem uznania przez nie potrzeby istnienia Polski, jako trwałego elementu układu sił $\mathrm{w}$ tej części kontynentu. Po odsunięciu niebezpieczeństwa, wynikającego ze zbytniego wzrostu potęgi monarchii piastowskiej poprzez jej osłabienie, doszły one bowiem do wniosku, iż w ich interesie politycznym leży udzielenie wsparcia Kazimierzowi w dziele jej rekonstrukcji. Gdybyśmy zatem jako negatywne czynniki ramowe opisywanej sytuacji uznali przewagę militarną sąsiadów, których najazdu Polska nie była w stanie skutecznie odeprzeć, oraz kryzys wewnętrzny spowodowany ruchami

${ }^{1}$ D. Borawska, Kryzys monarchii wczesnopiastowskiej w latach trzydziestych XI wieku, Warszawa 2013. 
odśrodkowymi (buntem ludowym i separatyzmem Mazowsza), to jednocześnie na ich listę musimy wpisać okoliczności pozytywne: brak woli (a może i możności) całkowitego zniszczenia państwa polskiego przez sąsiadów oraz ich gotowość do wspierania procesu jego odbudowy motywowaną uznaniem korzyści z jego trwałego istnienia. Polska w międzynarodowym układzie sił stawała się elementem niezbędnym dla zachowania jego równowagi.

Kolejne kryzysy, jakie państwo polskie przeżywało w połowie XVII w., w epoce wojen kozackich, moskiewskich i najazdu szwedzkiego oraz pod koniec XVIII w., rozgrywały się przy istotnie zmieniających się czynnikach ramowych, których suma niebezpiecznie ewoluowała w kierunku wartości ujemnych. Rzeczpospolita połowy XVII w. była wciąż jeszcze potężnym państwem o sporym autorytecie międzynarodowym i ważącym potencjale militarnym, zdolnym do stawiania długotrwałego oporu zaborczym sąsiadom. Ich przewaga militarna, zwłaszcza przy czasowej koincydencji różnych wojen, ujawniała się jednak coraz wyraźniej, choć nie musiała jeszcze mieć cech trwałości. Pojawiła się też idea rozbioru państwa polskiego pomiędzy sąsiadów (Szwecję, Moskwę, Brandenburgię, Siedmiogród z wykrojeniem dzielnicy dla Bogusława Radziwiłła i usamodzielnieniem się ziem ruskich objętych powstaniem Bohdana Chmielnickiego) sformułowana układem w Radnot w 1656 r. $^{2}$ Wówczas jednak sąsiedzi owi byli jeszcze zbyt słabi, a Polska zbyt silna i mogąca wciąż liczyć na wsparcie innych podmiotów politycznych, niezainteresowanych jej upadkiem (Danii, Austrii, chanatu krymskiego, a ostatecznie nawet Moskwy), aby plan ten mógł zostać zrealizowany. Przez cały wiek XVIII czynniki ramowe zmieniały się na gorsze, aż kolejny kryzys w jego ostatnim trzydziestoleciu okazał się dla państwa śmiertelny. Które z nich okazały się tym razem aż tak negatywne, że ich suma przewyższyła wartość tych, które wspierały dalsze istnienie konstrukcji państwowej I Rzeczypospolitej? Nicość militarna Rzeczypospolitej wobec potęgi sąsiadów była rażąca, odparcie najazdu zewnętrznego zatem mało możliwe. Bez załamania obcego wpływu krępującego możliwości zmian, uzdrowienie wewnętrzne państwa, rozumiane jako reforma ustrojowa, także okazywało się niemal nieosiągalne ${ }^{3}$. Słabość struktur państwowych, w tym także armii, powiększała się w relacji do sąsiadów przez dziesięciolecia

${ }^{2}$ K. Żojdź, Traktat z Radnot i udział Bogusława Radziwiłła w planach podziału Rzeczypospolitej, „Studia Historyczno-Wojskowe” 5, 2015, s. 176-194; M. Stangreciuk, Traktat w Radnot (6 grudnia 1656) jako pierwsza próba rozbioru ziem Rzeczypospolitej. Przyczyny, realizacja, w: Z dziejów stosunków Rzeczypospolitej Obojga Narodów ze Szwecją w XVII wieku, red. M. Nagielski, Warszawa 2007, s. 215-224.

3 Z. Zielińska, Polska w okowach „systemu pótnocnego” 1763-1766, Kraków 2012. 
i owych zapóźnień nie sposób było nadrobić w przeciągu kilku lat Sejmu Wielkiego. Jednocześnie znaczenie państwa polsko-litewskiego na arenie międzynarodowej - jako siły, o której poparcie warto byłoby zabiegać w różnych kombinacjach politycznych - słabło od początku XVIII w. Rzeczpospolita przestała być koniecznym czynnikiem zachowania równowagi międzynarodowej i atrakcyjnym partnerem do zawierania sojuszy. Stawała się jedynie polem walki dla obcych wojsk, aż w końcu uznana została za zbędny element ładu europejskiego - łup, którego terytorium można się podzielić, byleby zrobić to tak, aby zachować równowage pomiędzy pozostałymi uczestnikami gry międzynarodowej. Tym razem czynnik ramowy w postaci zewnętrznych podmiotów politycznych gotowych wspierać swym potencjałem - także militarnym - dalsze istnienie Polski nie wystąpił lub okazał się zbyt słaby (Turcja tocząca wojny z Rosją w latach 1768-1774 i 1787-1792), aby jego oddziaływanie przeważyło negatywny wpływ pozostałych czynników, takich jak wspomniana przewaga militarna mocarstw ościennych, ich gotowość do zrealizowania programu całkowitego wymazania Polski z mapy politycznej Europy, słabość polskich wewnętrznych struktur państwowych i brak determinacji tak elit, jak i społeczeństwa w obronie egzystencji państwa.

Historia zna także dzieje innych dokonanych lub jedynie planowanych rozbiorów państw. Być może nie były one tak spektakularne jak upadek Rzeczypospolitej, dużego państwa w centrum Europy, niemniej jednak, porównując inne podobne do tego wydarzenia, można pokusić się o pewne uogólniające obserwacje. W pomysły rozbiorowe obfitował zwłaszcza wiek XVIII. Być może jako jeden z czynników prowokujących powstawanie tego typu planów należy wskazać ogólną kulturę polityczną epoki, bazującą na przekonaniu, iż państwo jest w istocie strukturą polityczną z łaski Boga poddaną berłu określonego władcy, a zatem jego podział i przejęcie suwerenności nad danym terytorium wiąże się jedynie ze zmianą poddaństwa jakiejś części ludności, której lojalność (przy niedocenianiu wagi czynnika narodowego) nie będzie większym problemem. Mamy zatem plany podziału monarchii habsburskiej podczas wojen śląskich (1740-1742 i 1744-1745), gdy po schedę po niej miały sięgnąć Bawaria, Francja, Prusy i Saksonia. Groźna dla Habsburgów koalicja doprowadziła co prawda do trwałej utraty przez Wiedeń Śląska na rzecz Prus, ale okazała się zbyt słaba, by zrealizować plan rozbioru. Maria Teresa mogła liczyć na poparcie Anglii i Sabaudii oraz na chwiejność koalicji, z której czasowo występowały walczące z nią państwa (Prusy i Bawaria, a Saksonia stała się nawet jej sojusznikiem) ${ }^{4}$.

${ }^{4}$ H. Wereszycki, Historia Austrii, Wrocław 1986, s. 122-125. 
Zatem obserwowalny także w kryzysach państwowości polskiej w XI i XVII w. czynnik oddziaływania innych podmiotów politycznych na rzecz utrzymania państwowości wystąpił i w tym habsburskim przypadku. Wraz z pozostałymi warunkami ramowymi - dużym potencjałem własnym i siłą militarną Habsburgów, sprawnymi strukturami administracyjnymi, brakiem liczących się ruchów odśrodkowych (Węgrzy poparli wówczas sprawę Marii Teresy) - zdołał zrównoważyć czynniki negatywne: siłę militarną koalicji antyhabsburskiej i jej polityczną wolę przeprowadzenia idei rozbioru monarchii austriackiej.

Wkrótce w okresie wojny siedmioletniej (1756-1763) pojawiły się plany podziału Prus, rozważane w gronie koalicji stworzonej przez Austrię, Francję, Rosję, Saksonię i Szwecję. Mimo poniesionych kilku porażek, a nawet przejściowej okupacji Berlina, siła armii Fryderyka II i determinacja tak samego króla, jak i pruskich elit państwowych wykazywana w obronie państwa, pozostawały bardzo znaczące. Być może jednak okazałyby się niewystarczające, gdyby nie „cud domu brandenburskiego" - tj. nagłe wycofanie się Rosji z koalicji antypruskiej, a nawet przejście jej na stronę Prus, spowodowane decyzją nowego cara Piotra III - następcy zmarłej w trakcie wojny carowej Elżbiety - nienawidzącej Fryderyka II i zdecydowanie wrogiej monarchii pruskiej. Zafascynowany Prusami Piotr III swoją decyzją prawdopodobnie uratował ich istnienie ${ }^{5}$.

Wystąpienie tego niespodziewanego czynnika - tj. zaskakującego zwrotu politycznego spowodowanego dość przypadkową decyzją jednego człowieka, to okoliczność rzadko wpływająca w tak wyrazisty sposób na rozstrzygnięcia istotnych kwestii politycznych. Podobne nagłe zmiany linii politycznej możliwe są przeważnie wyłącznie w systemach opartych na jedynowładztwie czy w totalitaryzmach. Dają też duże pole do rozważań na temat roli przypadku w historii. Niemniej jednak należy je odnotować i umieścić na liście warunków ramowych towarzyszących upadkom państw. Czynnik przypadkowego wystąpienia pewnej okoliczności może zresztą oddziaływać w obie strony - odsłaniać nagle niespodziewaną szansę wyjścia z beznadziejnej sytuacji lub odwrotnie - zapoczątkowywać kryzys państwa (np. śmierć króla Władysława IV niemal jednoczesna ze zgonem hetmana Stanisława Koniecpolskiego - pozbawiająca Rzeczpospolitą doświadczonych wodzów w przededniu powstania kozackiego). Prusy miały zresztą przeżyć jeszcze jeden groźny kryzys, który zbliżył je do całkowitego upadku - klęskę w wojnie z napoleońską Francją z lat

${ }^{5}$ A. Kamieński, Polityka zagraniczna i wojny Fryderyka II w latach 1740-1763, w: Prusy w okresie monarchii absolutnej (1701-1806), red. B. Wachowiak, Poznań 2010, s. 261-276. 
1806-1807, gdy w wyniku katastrofy w bitwach pod Jeną i Auerstedt, po pogromie armii, nastąpił faktycznie rozpad państwa pruskiego, a na części jego terytorium (Wielkopolska) wybuchło polskie powstanie narodowe. O przetrwaniu monarchii pruskiej zadecydowała wtedy nie siła jej struktur państwowych i armii, bo te zostały zdruzgotane, ale włączenie się do wojny po jej stronie Rosji i brak determinacji Napoleona I w dążeniu do zniszczenia, czy jeszcze bardziej znaczącego okrojenia terytorialnego państwa pruskiego - a zatem przede wszystkim czynniki zewnętrzne ${ }^{6}$.

Wreszcie mamy też przykład niezrealizowanego planu rozbiorowego w XIX w. w czasie wojny paragwajskiej 1864-1870, kiedy to koalicja Brazylii, Argentyny i Urugwaju toczyła wojnę z Paragwajem, doprowadzając ów kraj do ruiny, zajmując część jego terytorium i czasowo okupując resztę. Jakkolwiek częściowy rozbiór Paragwaju pozbawił go na rzecz Argentyny i Brazylii ok. 25 proc. terytorium, to jednak ostatecznie udało mu się zachować niepodległość za cenę jednak olbrzymich strat ludnościowych. Istnienie okrojonego państwa uratowała w tej sytuacji Brazylia, odrzucając argentyńską propozycję całkowitego rozbioru sąsiada i okupując zagrożone przez Argentyńczyków paragwajskie terytoria (a w istocie chroniąc je przed zakusami Buenos Aires) aż do 1876 r. A zatem w opisywanym przypadku ponownie to czynnik zewnętrzny i jego wsparcie dla istnienia sąsiedniego państwa, uznawanego przezeń za pożyteczny element równowagi w regionie, zapobiegły ostatecznemu zniknięciu Paragwaju z mapy politycznej świata. Samo niebezpieczeństwo utraty niepodległości zostało jednakże sprowadzone przede wszystkim przez błędną, agresywną wobec państw ościennych politykę dyktatora Paragwaju - Francisca Solano Lópeza. Można by zatem powiedzieć, iż sam Paragwaj stworzył warunki do własnego unicestwienia, prowokując wojnę, której nie mógł wygrać 7 .

Upadek wielu państw w przededniu i w trakcie II wojny światowej dostarcza kolejnych wartych analizy wydarzeń tego rodzaju. Anschluss Austrii jest przykładem bezkrwawego podboju sąsiedniego państwa, którego wola oporu została uprzednio sparaliżowana. Przynajmniej część

${ }^{6}$ B. Engelmann, Prusy. Kraj nieograniczonych możliwości, Poznań 1984, s. 199-213; D. Łukasiewicz, Wojna 1806/1807 i traktat w Tylży, w: Prusy w dobie kształtowania się kapitalizmu (1806-1871), red. G. Kucharczyk, Poznań 2014, s. 23-50.

${ }^{7}$ J. Dobrzelewski, Wojna Paragwaju z potrójnym przymierzem 1864-1870, Zabrze-Tarnowskie Góry 2016; Dzieje Ameryki Łacińskiej od schyłku epoki kolonialnej do czasów wspótczesnych, t. 1: 1750-1870/1880, red. T. Łepkowski, Warszawa 1977, s. 356-367; t. 2: 1870/18801929, red. R. Mroziewicz i R. Stemplowski, Warszawa 1979, s. 169-173; J. Wojtczak, Wojna paragwajska 1864-1870, Warszawa 2011. 
jego mieszkańców sprzyjała takiemu rozwiązaniu, popychana do tego względami ideologicznymi i narodowymi. Jednocześnie działo się to w otoczeniu międzynarodowym, które bądź akceptowało zachodzące zmiany, bądź - choć oceniało je negatywnie - nie było gotowe przeciwstawić się im siłą, a zatem pozostało bierne. Bardziej skomplikowany wydaje się proces rozbioru Czechosłowacji. Jej kryzys wewnętrzny, jakkolwiek miał silne podstawy w separatyzmie licznych mniejszości narodowych (Niemców sudeckich, Węgrów, Słowaków, Rusinów, wreszcie Polaków ze Śląska Cieszyńskiego), był tylko jednym z warunków ramowych, inspirowanym i silnie wspieranym przez czynniki zewnętrzne - III Rzeszę, potem także Węgry i Polskę. Różnorodna struktura narodowościowa Republiki Czechosłowackiej od jej zarania stanowiła potencjalne źródło zagrożeń dla jej egzystencji. Błędy popełniane w polityce wewnętrznej i zagranicznej (zantagonizowanie Polski, lekceważenie autonomicznych dążności Słowaków, trwałe zantagonizowanie Węgrów poprzez przyłączenie do ČSR terytoriów etnicznie węgierskich, przy nieusuwalnym w ówczesnych warunkach obciążeniu ponad trzymilionową mniejszością niemiecką w Sudetach), osamotnienie na arenie międzynarodowej, mimo formalnie obowiązującego sojuszu z Francją, wreszcie słabość moralna własnych elit politycznych zadecydowały o kapitulacji I Republiki bez próby oporu zbrojnego i przyjęciu postanowień konferencji monachijskiej. Skutkowała ona najpierw okrojeniem terytorialnym państwa, a wkrótce jego całkowitym rozpadem przy inkorporacji części terytoriów przez sąsiadów ${ }^{8}$. Na tym tle czwarty rozbiór Polski, przeprowadzony w niecały rok później przez III Rzeszę niemiecką i ZSRR, jawi się jako wydarzenie nieco innej natury. Zdeterminowane w postanowieniu o podjęciu obrony przed obcym najazdem państwo upadło pod ciosami przeważającej potęgi militarnej sąsiadów, ale nie uznało się za ostatecznie pokonane i wymazane z mapy politycznej Europy, a jedynie za znajdujące się pod czasową okupacją najeźdźców.

Jakkolwiek upadek każdego państwa jest procesem specyficznym, warunkowanym właściwymi mu okolicznościami i w tym sensie niepowtarzalnym, porównanie tego typu wydarzeń może prowadzić do sformułowania pewnych ogólnych wniosków. Historia zna wiele przykładów zniszczenia państw na skutek obcych najazdów i podbojów. Tu okoliczności są tak różne, że za jedyny wspólny ich mianownik można uznać obcą przemoc, której dane państwo nie potrafiło się przeciwstawić. Możemy jednak wskazać pewne kategorie takich - najczęściej nagłych - katastrof politycznych, ograniczając się zaledwie do egzemplifikacji pewnego

${ }^{8}$ H. Batowski, Rok 1938 - dwie agresje hitlerowskie, Poznań 1985. 
„typu upadku” struktury państwowej bez możliwości wskazania w tym miejscu mnogości innych podobnych wydarzeń. Przywołajmy zatem „upadki bezpowrotne" potężnych w chwili wystąpienia kryzysu państw, których egzystencja została przerwana nagle, nie w wyniku rozwijających się przez lata czy dziesięciolecia problemów wewnętrznych, słabnięcia ich struktur, wzmagania się ruchów dezintegracyjnych, kłopotów gospodarczych itp., ale będące skutkiem druzgocącego uderzenia zewnętrznego, przesądzającego o ich losie. Do tego typu katastrof doszło podczas konkwisty - podboju przez Hiszpanów imperium Azteków ${ }^{9}$ czy Inków ${ }^{10}$. Były to $w$ istocie wydarzenia nagłe - ograniczone do kilku lat, które w wyniku druzgocącej przewagi technicznej wojsk hiszpańskich doprowadziły do trwałego wymazania z mapy politycznej świata potężnych organizmów państwowych, zapewne niezagrożonych (mimo istnienia pewnych zawirowań wewnętrznych - jak świeżo zakończona wojna domowa w państwie Inków czy gotowych do sprzymierzenia się ze zdobywcą Meksyku Hernandem Cortezem państewek indiańskich wrogich Aztekom) upadkiem, gdyby ów czynnik zewnętrzny nie wystąpił. Podobny czynnik, tj. podbój zewnętrzny, choć rozłożony w czasie na trzy wojny punickie, zdeterminował także los starożytnej Kartaginy ${ }^{11}$. Dla trwałego wymazania tych państw z mapy politycznej świata konieczne okazało się nie tylko militarne złamanie ich sił obronnych, ale i całkowite zniszczenie dawnych struktur państwowych, zastąpienie ich nowym systemem administracyjnym oraz znacząca ilościowo kolonizacja podbitego terytorium ludnością napływową, zmieniającą strukturę etniczną i tożsamość cywilizacyjną regionu. A zatem za owym pierwszym druzgocącym ciosem musiały iść następne, aby podbój w pełni skonsumować i przypieczętować jego trwałość.

„Upadek bezpowrotny” może być jednak determinowany zupełnie innymi okolicznościami. Zniknięcie istniejącej przez wieki i do niedawna potężnej, wielonarodowej monarchii habsburskiej, będące wynikiem I wojny światowej, miało swe źródła nie tylko w klęsce wojennej - nie pierwszej zresztą $\mathrm{w}$ dziejach owego państwa i wcale nie tak druzgocącej, ale w ambicjach politycznych narodów wchodzących w skład owej monarchii. Wojna była $\mathrm{w}$ tym wypadku istotnym, ale tylko katalizatorem procesów, które drążyły naddunajskie mocarstwo od dawna, a przynajmniej od połowy XIX w. stały się źródłem jego poważnych kłopotów i rosnącej słabości. Przy czym nie tyle nawet wola poszczególnych

\footnotetext{
9 T. Hugh, Podbój Meksyku, Katowice 1998 (oryg. ang. 1993).

10 W.H. Prescott, Podbój Peru, Warszawa 1969 (oryg. ang. 1847).

${ }^{11}$ K. Kęciek, Dzieje Kartagińczyków. Historia nie zawsze ortodoksyjna, Warszawa 2003.
} 
narodów wybicia się na niepodległość (przed I wojną światową program pełnej niepodległości formułowali jedynie Polacy), ile brak wystarczająco silnych czynników, mogących popychać owe nacje do podtrzymania dotychczas istniejącej struktury państwowej, zadecydował o jej ostatecznym upadku. Po prostu, w obliczu katastrofy wojennej siły wewnętrzne monarchii, które dążyłyby do jej utrzymania i odbudowania jej pozycji międzynarodowej, okazały się zbyt słabe wobec ruchów odśrodkowych narodów wybierających budowę własnej przyszłości w oddzielnych państwach narodowych powstających na jej gruzach. Przy braku istnienia narodu habsburskiego, w epoce, w której czynnik narodowy wyrastał na fundament, na którym budowano struktury państwowe, dalsza egzystencja monarchii stworzonej w poprzednich epokach ze zlepka różnorodnych etnicznie terytoriów okazała się anachronizmem. Zabrakło zatem podstawowego warunku ramowego, którego spełnienie jest conditio sine qua non istnienia państwa - nie było zbyt wielu chętnych do poświęcania czegokolwiek dla jego utrzymania ${ }^{12}$.

Z wszelkimi oczywistymi różnicami, można by to twierdzenie odnieść także do rozpadu Jugosławii po szeregu wojen na Bałkanach w latach dziewięćdziesiątych XX w. Zanik woli jej obywateli do pozostawania w jednym wspólnym państwie miał swoje źródła w zróżnicowanej (mimo pokrewieństwa etnicznego) strukturze narodowej owego organizmu politycznego, na którą nałożyły się różnice religijne i kulturowe. Pełna krwawych epizodów i zadawnionych urazów historia wzajemnych stosunków Słowian południowych dostarczała aż nadto pretekstów do odnowienia konfliktów. Ambicje zdominowania federacji przejawiane przez Serbów i odśrodkowe dążenia pozostałych tworzących ją narodów dały modelowy przykład rozpadu tego typu tworów państwowych. Wreszcie zmiana otoczenia zewnętrznego poprzez zanik integralnego charakteru bezpieczeństwa międzynarodowego otworzyła możliwość wybuchu konfliktu, który już nie musiał przekształcić się w starcie dwóch rywalizujących dotąd bloków politycznych Wschodu i Zachodu, a mógł pozostać konfliktem lokalnym, niegrożącym destabilizacją w skali globalnej, a zatem do pomyślenia i do tolerowania przez otoczenie międzynarodowe ${ }^{13}$. Te okoliczności tworzyły zatem owe warunki ramowe zaniku państwowości jugosłowiańskiej, który dziś - z dużą dozą prawdopodobieństwa można oceniać jako ostateczny.

${ }^{12}$ H. Batowski, Rozpad Austro-Węgier 1914-1918. Sprawy narodowościowe i działania dyplomatyczne, Kraków 1982.

13 I. Rycerska, Rozpad Jugosławii. Przyczyny i przebieg, Kielce 2003; W. Walkiewicz, Jugosławia. Byt wspólny i rozpad, Warszawa 2000. 
Znacznie spokojniejszy - wręcz ,aksamitny" - charakter miał rozpad Czechosłowacji ${ }^{14}$. W tym wypadku czynnikami stymulującymi były głównie ambicje posiadania własnego państwa narodowego przez Słowaków, mających poczucie pewnej dyskryminacji w dotychczas wspólnej republice i przekonanie Czechów, iż w istocie dotują słabszą gospodarczo i biedniejszą Słowację, która w dodatku odwzajemnia się za to podejrzliwością i niewdzięcznością wobec Pragi. I w tym wypadku sam problem, polegający na trudnościach w znalezieniu satysfakcjonującego obie strony sposobu ułożenia wzajemnych stosunków, nie był nowy. Stał się wszak jednym z czynników warunkujących upadek ČSR w 1938 r. Spetryfikowany na ponad 40 lat w strukturach zewnętrznego imperium sowieckiego, odżył wkrótce po zmianie sytuacji geopolitycznej, wymuszającej dotąd jego tłumienie. Zatem przy zasadniczych wewnętrznych źródłach wiodących do rozpadu i zaniku państwa, dla uruchomienia tego procesu konieczna okazała się zmiana otoczenia międzynarodowego opisywanego podmiotu politycznego.

$\mathrm{Z}$ rozpadem olbrzymiego imperium, choć nie całkowitym zniknięciem dawnych struktur państwowych, mieliśmy do czynienia przy okazji upadku Związku Sowieckiego. Przyczyny tego procesu - tak wewnętrzne (struktura narodowościowa, taki a nie inny podział na republiki związkowe, stan gospodarki, upadek ideologii, brak innego dostatecznego spoiwa, walka o władzę na Kremlu, procesy demograficzne w ZSRR, dążenia niepodległościowe narodów podbitych itd.), jak i zewnętrzne (przegrana zimna wojna w konfrontacji z Zachodem, coraz wyraźniejsze zacofanie cywilizacyjne we wszystkich dziedzinach życia, utrata tzw. imperium zewnętrznego i atrakcyjności ideologicznej oddziałującej na otoczenie międzynarodowe) - były rozliczne i skomplikowane. W ostatecznym efekcie przyniosły jednak dość nagłą i niespodziewaną implozję potężnego dotąd imperium wraz z drastycznym osłabieniem pozycji międzynarodowej jego dotychczasowego centrum i załamaniem gospodarczym na całym obszarze byłego ZSRR ${ }^{15}$. Nie ma żadnych przesłanek pozwalających wątpić, że w tym wypadku mieliśmy do czynienia z ostatecznym rozpadem owego państwa, którego ponowna integracja jest niemożliwa. Decydują o tym dwa podstawowe czynniki - brak woli większości dawnych części składowych imperium do ponownej integracji oraz brak siły centrum do dokonania ponownego ich podboju wbrew ich woli.

${ }^{14}$ P. Ukielski, Aksamitny rozwód. Rola elit politycznych w procesie podziału Czechosłowacji, Warszawa 2007.

15 W. Marciniak, Rozgrabione imperium. Upadek Związu Sowieckiego i powstanie Federacji Rosyjskiej, Kraków 2001. 
Jest to być może dobry moment, by zastanowić się nad możliwościami, jakie stoją przed centrum imperium co do możliwego wyboru linii politycznej wobec jego peryferii. Zasadniczo są dwa kierunki postępowania - brutalne tłumienie siłą wszelkich ruchów odśrodkowych i utrzymywanie jedności za pomocą terroru skierowanego wobec wszelkich przejawów separatyzmu (jest to model stosowany przez np. imperium rosyjskie), albo daleko posunięta autonomia z akceptacją nawet pełnej niepodległości tych części imperium, które tego zażądają (to model anglosaski prowadzący do Commonwealthu) ${ }^{16}$.

Taki uproszczony podział pozwala na jasną kwalifikację istniejących modeli działania, ale nie oddaje oczywiście znacznie bardziej złożonej rzeczywistości politycznej, warunkującej i ograniczającej w praktyce decyzje, które mogą być podejmowane w tym względzie. Kształtują je bowiem nie tylko pojawiające się chwilowe dylematy polityki imperialnej (konieczność reakcji na zaistniały kryzys jedności imperium), ale i ogólna kultura polityczna metropolii, panujący w niej system polityczny (bardziej demokratyczny czy bardziej autorytarny), istnienie lub nieistnienie opinii publicznej zdolnej oddziaływać na politykę rządu w tym czy innym kierunku, wreszcie doświadczenia i wnioski wyciągnięte z poprzednich kryzysów. Jak mogą być one różne, przekonuje przykład Wielkiej Brytanii, która po utracie kolonii północnoamerykańskich, z chwilą pojawienia się nowego kryzysu politycznego grożącego separatyzmem Kanady pod koniec lat trzydziestych XIX w., uznała, że siłowe rozwiązanie kryzysu jedynie wzmocni tendencje irredentystyczne i zdecydowała się przyznać owej kolonii status dominium z szeroką autonomią ${ }^{17}$, co okazało się wkrótce ogólnym modelem stosunków metropolii z koloniami brytyjskimi, aż do przekształcenia imperium w Commonwealth - dobrowolny związek równoprawnych państw. Metropolie, które wybrały drogę represji i siłowego tłumienia buntu, bez wyjątku utraciły swoje dawne imperia, staczając w ich obronie często krwawe wojny, niemogące jednak uratować ich jedności (np. Hiszpania w XIX w. w Ameryce Łacińskiej, Francja w XX w. w Wietnamie i Algierii).

Ciekawym przykładem próby ratowania imperium za pomocą wyboru różnych metod postępowania była osmańska Turcja. W tym wypadku doświadczenie Stambułu skłoniło go w końcu do wyboru drogi represji, a nie poszerzania autonomii. Przyznawanie jej bowiem Serbii czy Bułgarii zawsze kończyło się ostatecznie utratą obdarowanej nią prowincji

${ }^{16}$ N. Ferguson, Imperium. Jak Wielka Brytania zbudowała nowoczesny świat, Kraków 2013 (oryg. ang. 2003).

17 P. Wróbel, A. Wróbel, Kanada, Warszawa 2000, s. 23-90. 
i powstaniem przy granicach wrogiego Turcji państwa. To doświadczenie było zatem jednym (bo nie jedynym) z czynników, które spowodowały, iż z chwilą pojawienia się separatyzmu ormiańskiego Stambuł nie poszedł już tą drogą i nie przyznał Armenii autonomii, ale zdecydował się na eksterminację ludności buntującej się prowincji i siłowe utrzymanie jej w ramach imperium osmańskiego ${ }^{18}$, co zresztą nie ocaliło go przed rozpadem i utratą wielu innych obszarów na Bałkanach, na Bliskim Wschodzie i w Afryce.

Odbudowa czy budowa państw na nowo powstających do życia jest także warunkowana pewnymi czynnikami ramowymi. Jest możliwa tylko w sytuacji kryzysu panowania nad danym terytorium innego podmiotu politycznego. Źródła tego kryzysu mogą być wielorakie - klęska militarna wpływająca na zachwianie bądź nawet zdruzgotanie dotychczas istniejących struktur państwowych, katastrofa gospodarcza osłabiająca dotychczasowe centrum, przekształcenia ustrojowe otwierające droge do ewolucyjnego wybicia się na niepodległość części jakiegoś państwa dotąd siłą utrzymywanych w jego ramach. Podobnie koniecznym warunkiem odbudowy upadłego niegdyś państwa jest wola polityczna znaczącej części mieszkańców danego terytorium do zbudowania odrębnych i niezależnych od zastanych struktur państwowych. Wola ta musi jednakże trafić na odpowiednią koniunkturę polityczną, często jest też wsparta działaniami innych podmiotów zewnętrznych na korzyść państwa powstającego (np. Grecji w XIX w.). Jak w przypadku dezintegracji i upadku, tak i odnośnie do odbudowy i odrodzenia mnogość możliwych scenariuszy wyklucza ich szczegółowe dokładne opisanie. Możemy jednakże skonstatować, że pośród owych warunków ramowych koniecznych dla uruchomienia procesu restauracji jakiejś państwowości musi zaistnieć przede wszystkim wystarczająco silne dążenie przyszłych obywateli odradzającego się państwa do jego odbudowy. To z kolei jest stymulowane pamięcią historyczną, zachowaniem tradycji - choćby nawet na wpół legendarnej - istnienia kiedyś własnego suwerennego organizmu państwowego oraz wystarczającym do podjęcia próby jego odtworzenia potencjałem politycznym. Prawdopodobieństwo sukcesu jest przy tym odwrotnie proporcjonalne do czasu, który upłynął od upadku państwa do podjęcia próby jego odrodzenia (im dłuższy, tym jest ono mniejsze), oraz głębokości zmian mentalnych, struktury społecznej, demograficznych, etnicznych i kulturowych na jego dawnym obszarze. Nie do pominięcia jest przy tym jak zwykle sprzyjająca takiemu procesowi koniunktura międzynarodowa.

${ }^{18}$ Y. Ternon, Ormianie. Historia zapomnianego ludobójstwa, Kraków 2005 (oryg. franc. 1996). 
Restauracja państwa polskiego w 1918 r. ma w tym kontekście cechy wyjątkowe. Nastąpiła po dość długim okresie jego zniewolenia, ale jednak nie na tyle długim, aby żywa pamięć o jego istnieniu i wola jego odbudowy nie przetrwały jako zjawisko ciągłe, manifestowane w każdym pokoleniu okresu niewoli. Inne narody wybijające się w owym czasie na niepodległość albo swojego państwa nigdy nie posiadały, albo utraciły je na tyle dawno, że pamięć o nim przechowała się jedynie w legendzie i mogła służyć zaledwie budowie ideologii legitymizacyjnej dla powstającego - w istocie całkowicie nowego podmiotu politycznego. Trudno było czerpać wzory ustrojowe z dawnych wieków, gdy tradycja niepodległości sięgała zamierzchłych epok - średniowiecza czy początków ery nowożytnej. Odwoływanie się do wzorców dawnej państwowości i stosowanie ich przez Czechów, Irlandczyków czy Litwinów miało głównie wymiar symboliczny, a nie praktyczny. Z problemem tym spotkały się zresztą wcześniej także inne narody wybijające się na niepodległość jeszcze w XIX w. - np. Grecy, Serbowie czy Bułgarzy. Dla nich pamięć o dawnych suwerennych bytach politycznych oznaczała konieczność sięgania kilka stuleci w przeszłość, od której oddzielały ich całe wieki funkcjonowania $\mathrm{w}$ obcych organizmach państwowych ze śladowymi bądź żadnymi przejawami własnego, odrębnego życia narodowego. Ich struktura społeczna została zmieniona (warstwy wyższe wyginęły bądź się poturczyły), a jedyne znane empirycznie wzorce ustrojowe miały proweniencję osmańską, nie zaś rodzimą.

W Polsce - jakkolwiek wpływy obce także dokonały istotnych zmian w strukturze społecznej, ekonomicznej a nawet kulturowej poszczególnych dzielnic kraju - to jednak siła kultury rodzimej i pamięć o własnych wzorcach zachowań politycznych i tradycji państwowej była na tyle żywa oraz na tyle nowoczesna, iż mogła oddziaływać praktycznie na kształt powstającej do niepodległości II Rzeczypospolitej (dwuizbowy kształt parlamentu, nazwy urzędów i jednostek administracyjnych, elementy ceremoniału wojskowego i stopnie wojskowe, wiodąca kulturowa - bo już nie polityczna - rola warstwy inteligencko-ziemiańskiej, postszlachecka kultura narodowa odróżniana od ludowej itd.). Wreszcie to, co stanowi dla Polski rys charakterystyczny, to utrzymująca się w świadomych narodowo i - im bliżej niepodległości - coraz liczebniejszych warstwach społeczeństwa wiara w konieczne i nieuchronne odzyskanie przez nią niepodległego bytu, brak akceptacji dla obcego panowania uznawanego za czasowe, stałe zaprzeczanie jego legalności i postrzeganie narzuconych Polakom struktur politycznych jako obce i jedynie przymusowo 
do czasu znoszone. Dla podkreślenia czasowości i bezprawności granic dzielących kraj między zaborców nazywano je powszechnie kordonami, odmawiając miana legalnych linii granicznych. Niechaj jako ilustracja tego typu postaw (i jednocześnie pointa niniejszych rozważań), będących być może warunkiem fundamentalnym odbudowy państwowości polskiej, posłuży zachowanie Antoniego Wernickiego - oficera polskiego w służbie osmańskiej, uczestnika wojny rosyjsko-tureckiej 1877-1878 r., który, pochwycony do niewoli, został przez Rosjan rozpoznany jako Polak, oskarżony o zdradę i skazany na rozstrzelanie. Stojąc przed plutonem egzekucyjnym zarzut zdrady odpierał dumnym oświadczeniem: „Mój kraj do was nie należy”19.

Biogram: Radosław Paweł Żurawski vel Grajewski, dr hab., prof. Uniwersytetu Łódzkiego, kierownik Katedry Historii Powszechnej Najnowszej Instytutu Historii UŁ; zainteresowania badawcze: historia powszechna dyplomacji XIX w., ze szczególnym uwzględnieniem dziejów Imperium Brytyjskiego w pierwszej połowie XIX w., historia Wielkiej Emigracji po powstaniu listopadowym, historia powszechna dyplomacji w okresie II wojny światowej, zwłaszcza stosunków brytyjsko-czechosłowackich, problematyka mitów, stereotypów i tradycji narodowych; kontakt: rpzg@poczta.onet.pl.

19 J.S. Łątka, Z ziemi tureckiej do Polski. Dzieje legionu polskiego w Turcji 1877 r., Gdańsk 2000, s. 58. 